\title{
IDENTIFIKASI PREFERENSI KONSUMEN PRODUK KERUPUK JAMBU BIJI MERAH MENGGUNAKAN METODE QFD (QUALITY FUNCTION DEPLOYMENT)
}

\author{
Identification of Customer Preferences for Red Guava Crackers use QFD Method \\ Tyas Eka Kurnia ${ }^{1 *}$ dan Ande Tri Listanti ${ }^{1}$ \\ ${ }^{1}$ Institut Sains dan Teknlogi Al-Kamal, Jakarta, Indonesia
}

\section{Informasi artikel}

Diterima: $27 / 07 / 2019$

Direvisi : 29/07/2019

Disetujui: 30/07/2019

\begin{abstract}
Abstrak
Hasil pertanian jambu biji merah di Kabupaten Kendal bisa dikatakan cukup tinggi dan menjadi salah satu komoditas buah yang diunggulkan. Tingginya hasil produksi jambu biji merah tidak turut meningkatkan kesejahteraan para petani jambu biji merah, dikarenakan para petani menjualnya dalam keadaan segar, dimana tidak terdapat nilai tambah. Perlu adanya alternatif lain dalam menjual jambu biji merah agar dapat memberikan nilai tambah yaitu dengan mengolah jambu biji merah menjadi produk olahan.Penelitian ini bertujuan untuk mengidentifikasi keinginan konsumen terhadap kerupuk jambu biji merah, mengetahui atribut persyaratan teknis yang menjadi prioritas utama untuk dikembangkan dan mengetahui atribut keinginan konsumen yang paling mempengaruhi preferensi konsumen terhadap kerupuk jambu biji merah. Metode yang digunakan dalam penelitian ini adalah Quality Function Deployment (QFD). Dari analisa matriks House of Quality didapatkan sepuluh atribut keinginan konsumen dan lima belas atribut persyaratan teknis terhadap produk kerupuk jambu biji merah. Berdasarkan perhitungan nilai Improvement Ratio, terdapat sembilan atribut yang sudah sesuai dengan keinginan konsumen $(\mathrm{IR}=1)$ dan satu atribut yang belum sesuai dengan keinginan konsumen yaitu atribut tekstur renyah dan halus karena memiliki nilai IR sebesar $1,12 \quad(I R>1)$ sehingga perlu dilakukan adanya tindakan perbaikan. Atribut persyaratan teknis (Technical Requirment) yang menjadi prioritas utama untuk dikembangkan adalah konsentrasi jambu biji merah dalam adonan karena memiliki nilai prioritas tertinggi $(4,69)$. Atribut informasi tanggal produksi dan tanggal kadaluarsa pada label kemasan merupakan atribut yang paling mempengaruhi preferensi konsumen ketika membeli kerupuk jamu biji merah karena memiliki bobot kepentingan terbesar $($ TKK=4,69).
\end{abstract}

Kata Kunci: house of quality, jambu biji merah, kerupuk buah, quality function deployment.

\begin{abstract}
Agricultural products of red guava in Kendal is quite high and become one of the superior fruit commodities. The high production of red guava were not supossed to enhanching. There should have been an alternative in selling red guava in order to provide added value by processing the red guava processed into a product. The purpose of this purpose to identify consumers' needed for red guava crackers, knows attributes of technical requirements that become the main priority to be developed and to know the attribute of consumer that most affecting preference of consumer on red guava crackers. The method used in this research is Quality Function Deployment (QFD). From the analysis of House of Quality matrix, there are ten attributes of consumer needed and fifteen attribute of technical requirement to red guava cracker product. Based on the calculation of Improvement Ratio value, there are nine attributes that have been in accordance with consumer requirment $(I R=1)$ and one attribute that has not been in accordance with consumer requirment is crunchy texture and smooth because it has the value of $I R$ as much as 1,12 (IR>1) so there needs to be an corrective action. The technical requirement attributes that become the main priority to be developed because it has the highest priority value (4.69). attribute information the date of the production and the expiration date on a packaging label is the most influential attribute to consumer preference when buying red guava crackers because it has the greatest interest weight $(T K K=4,69)$.
\end{abstract}

Keywords: fruit crackers, house of quality, quality function deployment, red guava

*Penulis Korespondensi : Handphone: -

email : tyas.ista0117@gmail.com 


\section{PENDAHULUAN}

Semakin majunya zaman semakin variatif pula keinginan dan kebutuhan konsumen akan suatu produk atau jasa. Memahami konsumen adalah suatu keharusan yang sangat mutlak karena masing-masing konsumen memiliki kebutuhan, keinginan dan selera yang berbeda-beda, maka produk yang ditawarkan juga harus disesuaikan dengan keinginan dan kebutuhan konsumen yang semakin variatif tersebut. Adanya suatu inovasi pembuatan produk baru dan pengembangan suatu produk dari produk yang sudah ada, mutlak diperlukan jika kita menginginkan bisnis yang kita kelola bisa tetap bertahan. Tanpa inovasi sebuah usaha tidak bisa bertahan lama. Kegiatan merancang dan mengembangkan produk, baik yang berupa jasa maupun barang, tidak terlepas dari konsep pemasaran yang bertujuan memenuhi kebutuhan yang memuaskan pelanggan (Nasution, 2005).

Di Kabupaten Kendal saat ini jambu biji merah menjadi salah satu komoditas buah yang diunggulkan. Pada tahun 2015, produksi jambu biji merah mencapai 159.201 kwintal (Dinas Pertanian Kabupaten Kendal) dengan jumlah pohon sebanyak 107.005 pohon yang ditanam di atas lahan seluas $268 \mathrm{Ha}$. Walaupun hasil panen jambu biji merah di kabupaten Kendal cukup tinggi, namun belum dapat meningkatkan pendapatan para petani jambu biji merah. Hal tersebut dikarenakan para petani menjual jambu biji merah secara curah kepada tengkulak. Hal tersebut berdampak pada rendahnya harga jual jambu biji merah karena tidak memiliki nilai tambah. Selain itu jambu biji merah yang sudah matang atau menguning tidak laku dijual dan dibiarkan membusuk karena tidak ada yang mau mengkonsumsi atau memanfaatkannya. Salah satu cara yang dapat dilakukan untuk meningkatkan harga jual jambu biji merah adalah membuat produk olahan berbahan dasar jambu biji merah salah satunya adalah kerupuk. Kerupuk merupakan salah satu jenis produk makanan khas Indonesia yang sangat beragam baik dari segi cita rasa maupun nilai gizinya. Kerupuk dikenal sebagai makanan pembangkit selera makan atau pelengkap berbagai sajian makanan dan camilan yang bisa dikonsumsi dimana saja. Pemanfaatan buah jambu biji merah menjadi kerupuk buah merupakan suatu bentuk disversifikasi produk yang dapat meningkatkan keanekaragaman jenis kerupuk maupun olahan buah jambu biji merah. Selain itu, kerupuk jambu biji merah diharapkan dapat memberikan sumbangan zat gizi berupa energi.

Kerupuk jambu biji merah merupakan salah satu produk olahan buah yang tergolong baru dan belum banyak dikenal oleh masyarakat sehingga tingkat penerimaan dan keinginan konsumen terhadap karakteristik mutu produk ini belum diketahui secara pasti, baik dari segi fisik maupun rasa. Pada umumnya tidak semua konsumen memiliki preferensi yang sama akan kebutuhan suatu produk. Preferensi konsumen adalah pilihan suka atau tidak suka oleh seseorang terhadap produk yang akan dikonsumsi dari berbagai pilihan produk yang ada (Kotler, 2002). Adanya berbagai macam jenis kerupuk yang ditawarkan di pasaran tentunya membuat konsumen dihadapkan dengan berbagai alternatif yang ada sehingga konsumen cenderung mempunyai preferensi tertentu sebelum melakukan proses pengambilan keputusan. Kegunaan preferensi konsumen terhadap produk kerupuk jambu biji ini adalah untuk mengetahui apakah kerupuk jambu biji merah ini sesuai dengan yang diinginkan dan bisa diterima oleh konsumen atau tidak. Oleh karena itu diperlukan suatu metode yang bisa mengidentifikasi preferensi konsumen terhadap produk kerupuk jambu biji merah ini.

Quality Function Deployment (QFD)merupakan suatu metode yang digunakan untuk menangkap keinginan konsumen akan suatu produk (Gaspersz. 2001). Metode ini telah diakui di dunia sejak tahun 1960-an sebagai salah satu alat untuk menerjemahkan kebutuhan konsumen ke dalam spesifikasi produk (Rahmatika, 2008). Hasil dari QFD adalah kriteria keinginan konsumen akan suatu produk, serta atributatribut yang harus diperhatikan, sehingga produk yang dihasilkan dapat memenuhi tingkat kualitas yang memuaskan pelanggan. QFD sangat cocok untuk proses pengembangan produk baru sebagai bentuk antisipasi untuk membentuk spesifikasi produk dan cepat ditangani menurut. QFD mampu meningkatkan proses pengembangan produk dan menghasilkan produk yang sangat terfokus dan responsif terhadap kebutuhan pelanggan. Masalah dalam penelitian ini dirumuskan sebagai berikut:

1. Apakah harapan atau keinginan konsumen (Voice of Customer) terhadap 
produk kerupuk jambu biji merah?

2. Apakah atribut keinginan konsumen yang belum sesuai dengan harapan konsumen terhadap produk kerupuk jambu biji merah?

3. Apakah atribut persyaratan teknis (Technical Requirements) yang menjadi prioritas utama dalam proses pembuatan kerupuk jambu biji merah?

4. Apakah atribut keinginan konsumen yang paling berpengaruh terhadap preferensi konsumen ketika ingin membeli produk kerupuk jambu biji merah?

Tujuan dari penelitian ini adalah:

1. Mengidentifikasi harapan atau keinginan konsumen (Voice of Customer) terhadap produk kerupuk jambu biji merah.

2. Mengetahui atribut keinginan konsumen yang belum sesuai dengan keinginan konsumen terhadap produk kerupuk jambu biji merah.

3. Mengetahui persyaratan teknis (Technical Requirements) yang menjadi prioritas utama dalam proses pembuatan kerupuk jambu biji merah.

4. Mengetahui atribut keinginan konsumen yang paling berpengaruh terhadap preferensi konsumen ketika membeli kerupuk jambu biji merah.

Agar lebih fokus dan terarah terhadap tujuan penelitian maka diperlukan adanya batasan masalah. Batasan masalah dalam penelitian ini adalah:

1. Penelitian ini dilakukan dari bulan September sampai Desember 2017.

2. Pengolahan data pada penelitian ini menggunakan software SPSS versi 17 dan software Edraw Max versi 9.1.

3. Penyusunan matriks HOQ (House of Quality) fase satu yaitu tahap perencanaan produk kerupuk jambu biji merah.

\section{METODOLOGI}

Jenis penelitian yang digunakan adalah penelitian survei yaitu jenis penelitian dengan cara mengumpulkan informasi tentang karakteristik, tindakan, pendapat dari sekelompok responden yang representative yang dianggap sebagai populasi. Objek yang diteliti dalam penelitian ini adalah preferensi konsumen terhadap kerupuk jambu biji merah dengan memberikan kuisioner kepada responden yang berdomisili di daerah JABODETABEK.
Populasi dalam penelitian ini adalah masyarakat yang berdomisili di JABODETABEK baik pria maupun wanita dengan usia lebih dari 17 tahun dan pernah mengkonsumsi kerupuk buah. Penelitian ini dilakukan dengan mencari responden yang berdomisili di daerah JABODETABEK (Jakarta, Bogor, Depok, Tangerang, Bekasi). Penelitian ini dilaksanakan dari bulan September sampai Desember 2017. Besar sampel yang diambil adalah 100 responden berusia lebih dari 17 tahun.

Kerupuk jambu biji merah ini dapat dikonsumsi semua usia, namun untuk pengambilan sampel pada penelitian ini dibutuhkan pertanggungjawaban dalam pengisian kuisioner. Teknik pengambilan sampel dalam penelitian ini menggunakan metode accidental sampling. Accidental sampling merupakan teknik pengambilan sampel berdasarkan kebetulan, yaitu siapa saja yang secara kebetulan bertemu dengan peneliti dapat digunakan sebagai sampel, bila dipandang orang yang kebetulan ditemui itu cocok sebagai sumber data (Sugiyono. 2001)

Uji validitas pada penelitian ini adalah untuk mengetahui apakah atribut keinginan konsumen yang digunakan dalam kuesioner dapat benar-benar mengukur apa yang diinginkan konsumen terhadap produk kerupuk jambu biji merah. Tipe validitas yang digunakan adalah validitas konstruk yaitu yang menentukan validitas dengan cara mengkolerasikan antar skor dengan skor totalnya. Kolerasi antar skor item dengan skor totalnya harus signifikan. Pada penelitian ini, uji validitas menggunakan bantuan software SPSS versi 17. Kriteria yang digunakan untuk uji keabsahan butir jika $r$ hitung > $r$ tabel, maka butir instrumen dianggap valid, sedang jika $r$ hitung $<$ atau $=$ $r$ tabel maka butir instrumen dianggap tidak valid dan selanjutnya di drop atau tidak digunakan. Jumlah sampel penelitian diambil sebanyak 100 responden. Dari tabel $r$ product moment dengan taraf signifikan $5 \%$ didapat nilai sebesar 0,195.

Uji reliabilitas bertujuan untuk mengetahui apakah kuesioner hasil yang diperoleh dapat dipercaya atau tidak. Pengujian reliabilitas pada penelitian ini menggunakan bantuan software SPSS versi 17. Kriteria uji reliabilitas dengan rumus alpha adalah apabila $r$ hitung $>r$ tabel, maka alat ukur tersebut reliabel dan juga sebaliknya, jika $r$ hitung $<$ atau $=r$ tabel maka alat ukur tidak reliabel. 
Matriks House of Quality

1. Mengidentifikasi keinginan dan kebutuhan konsumen (Customer Requirements/Whats). Berisi tentang atribut produk kerupuk jambu biji merah yang menjadi kebutuhan dan keinginan konsumen.

2. Mengidentifikasi persyaratan teknis (Technical Requirements/Technical Description/Hows). Persyaratan teknis ini dihasilkan dari hasil diskusi antara peneliti, dosen pembimbing yang merupakan akademisi bidang pangan dan salah satu mahasiswa sebagai pelaku usaha atau pembuat kerupuk jambu biji merah. Setiap karakteristik yang ada harus berhubungan secara langsung dengan customer requirements.

3. Mengidentifikasi hubungan antar keinginan konsumen dengan persyaratan teknis (WHATs and HOWs) atau disebut dengan Relationship Matriks. Matriks hubungan ini merupakan interaksi antara Technical Requirements dengan Customer Requirements untuk menunjukkan kuat atau lemahnya hubungan tersebut yang dinotasikan dalam bentuk tanda/simbol dengan bobot angka yang berbeda sebagai berikut:

Tabel 1 Simbol dan Nilai Relationship Matrix

\begin{tabular}{ccl}
\hline Simbol & Nilai & \multicolumn{1}{c}{ Arti } \\
\hline Tanpa & 0 & Tidak ada \\
simbol & hubungan & Hubungan \\
$\triangle$ & 1 & $\begin{array}{l}\text { lemah } \\
\text { lemah }\end{array}$ \\
0 & 3 & $\begin{array}{l}\text { Hubungan } \\
\text { sedang }\end{array}$ \\
0 & 9 & Hubungan kuat \\
\hline
\end{tabular}

4. Mengidentifikasi hubungan antar persyaratan teknis (HOWs and HOWs) atau disebut dengan Interrelationship Matriks. Pembuatan matriks korelasi bertujuan untuk mengetahui hubungan antar persyaratan teknis dari produk kerupuk jambu biji merah. Pada penyusunan matriks ini, digunakan simbol untuk menyatakan derajat hubungan antar persyaratan teknis.
Tabel 2 Simbol Technical Corelation

\begin{tabular}{cc}
\hline Simbol & \multicolumn{1}{c}{ Hubungan } \\
\hline++ & Positif kuat \\
+ & Positif \\
Tanpa & Tidak ada hubungan \\
simbol & \\
- & Negatif \\
-- & Negatif kuat \\
\hline
\end{tabular}

5. Menyusun Matriks Perencanaan.

a) Tingkat Kepentingan Konsumen (Importance to Customer). Berisi tentang tingkat kepentingan tiap atribut kebutuhan konsumen.

b) Tingkat Kepuasan Konsumen (Importance to Customer). Berisi tentang bagaimana kinerja produk yang dikembangkan dapat memenuhi kepuasan konsumen.

c) Target (Goal). Menyatakan seberapa besar tingkat kinerja kepuasan yang diharapkan dapat dicapai oleh perusahaan untuk memenuhi setiap keinginan konsumen.

d) Rasio Perbaikan (Improvement Ratio) Perhitungan Improvement ratio dilakukan untuk mengetahui apakah perlu dilakukan perbaikan atau tidak terhadap suatu atribut kebutuhan konsumen.

e) Poin Penjualan (Sales Point), dilakukan untuk mengetahui bagaimana peranan masing-masing atribut kebutuhan konsumen terhadap penjualan produk. Nilai yang dipakai adalah 1 (no sales point), 1.2 (medium sales point), 1.5 (strong sales point).

f) Menentukan nilai Raw Weight dan Normalized Raw Weight. Raw weight merupakan bobot dari setiap atribut kebutuhan konsumen. Semakin besar nilai Raw Weight suatu atribut, semakin tinggi prioritas pengembangannya. Normalized raw weight merupakan persentase bobot suatu atribut kebutuhan konsumen terhadap keseluruhan bobot atribut kebutuhan konsumen untuk setiap atribut kebutuhan atau persen total dari Raw Weight. Hasil perhitungan nilai Raw Weight dan Normalized Raw Weight digunakan untuk menentukan prioritas persyaratan teknis yang harus diutamakan. 
6. Menentukan nilai prioritas dan kontribusi persyaratan teknis. Nilai prioritas persyaratan teknis menunjukkan seberapa penting suatu persyaratan teknis untuk dikembangkan. Semakin tinggi nilai prioritas suatu persyaratan teknis, maka semakin tinggi pula prioritas persyaratan teknis tersebut untuk dikembangkan. Nilai kontribusi menunjukkan kekuatan persyaratan teknis pada keseluruhan persyaratan teknis terhadap kepuasan konsumen. Kontribusi ditentukan dengan menghitung nilai prioritas dibagi dengan total nilai prioritas.

Untuk lebih mempermudah pemahaman dalam mempelajari dan melakukan penelitian ini, maka diperlukan suatu kerangka pemikiran yang jelas. Adapun kerangka pemikiran dalam penelitian ini adalah sebagai berikut:

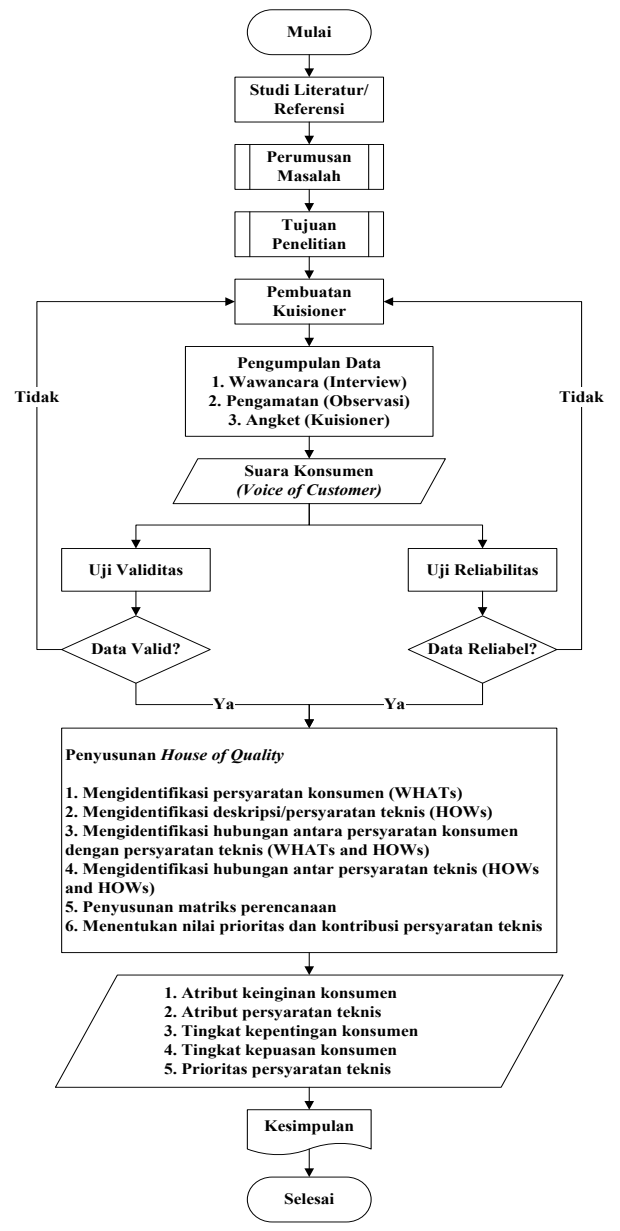

Gambar 1 Diagram alir penelitian

\section{HASIL DAN PEMBAHASAN}

1. Mengidentifikasi Keinginan dan Kebutuhan Konsumen (Customer Requirements/Whats) untuk mengidentifikasi keinginan konsumen terhadap kerupuk jambu biji merah, peneliti melakukan survei pendahuluan melalui kuesioner online kepada 100 responden yang berdomisili di JABODETABEK. Dari kuesioner pendahuluan tersebut, didapatkan 10 atribut keinginan konsumen terhadap kerupuk jambu biji merah yaitu sebagai berikut:

Tabel 3 Atribut keinginan konsumen

\begin{tabular}{|c|c|}
\hline Variabel & Atribut Keinginan Konsumen \\
\hline Produk & $\begin{array}{l}\text { Rasa original } \\
\text { Aroma khas jambu biji merah } \\
\text { Tekstur renyah dan halus }\end{array}$ \\
\hline Kemasan & $\begin{array}{l}\text { Dikemas menggunakan } \\
\text { kemasan plastik ziplock } \\
\text { Informasi tanggal produksi } \\
\text { dan tanggal kadaluarsa } \\
\text { Informasi komposisi produk } \\
\text { Informasi produsen dan label } \\
\text { merk }\end{array}$ \\
\hline Harga & $\begin{array}{l}\text { Rp } 7500 \text { per } 100 \text { gram produk } \\
\text { Rp } 12500 \text { per } 150 \text { gram produk }\end{array}$ \\
\hline Pemasaran & $\begin{array}{l}\text { Dijual di warung/toko dan } \\
\text { online shop }\end{array}$ \\
\hline
\end{tabular}

2. Uji Validitas

Data yang digunakan adalah data hasil kuesioner dari keinginan konsumen yang menghasilkan 10 atribut keinginan konsumen. Tujuan uji validitas pada penelitian ini adalah untuk mengetahui apakah atribut keinginan konsumen yang digunakan dalam kuesioner dapat benarbenar mengukur apa yang diinginkan konsumen terhadap produk kerupuk jambu biji merah. Perhitungan uji validitas pada penelitian ini dilakukan menggunakan software SPSS dengan $n=100, a=5 \%$ dan nilai $r$ tabel sebesar 0,195 . Nilai perhitungan yang dihasilkan dibandingkan dengan nilai $r$ tabel. Jika nilai $r$ hitung $>r$ tabel, maka atribut atau instrumen tersebut dinyatakan valid. Jika nilai $r$ hitung $<r$ tabel maka atribut atau instrumen tersebut dinyatakan tidak valid.

Berdasarkan hasil perhitungan uji validitas yang telah dilakukan, didapatkan hasil bahwa semua atribut keinginan konsumen produk kerupuk jambu biji merah bersifat valid yaitu dapat mengukur apa yang ingin diukur. Hal tersebut dikarenakan nilai $r$ hitung dari masing-masing atribut keinginan konsumen lebih besar dari nilai $r$ tabel. 


\section{Uji Reliabilitas}

Uji reliabilitas pada penelitian ini bertujuan untuk mengetahui apakah kuesioner hasil yang diperoleh dapat dipercaya atau tidak. Perhitungan uji reliabilitas pada penelitian ini dilakukan menggunakan software SPSS dengan $n=100$, $a=5 \%$ dan nilai $r$ tabel sebesar 0,195 . Nilai perhitungan yang dihasilkan dibandingkan dengan nilai $r$ tabel. Jika nilai $r$ hitung $>r$ tabel, maka atribut atau instrumen tersebut dinyatakan valid. Jika nilai $r$ hitung $<r$ tabel maka atribut atau instrumen tersebut dinyatakan tidak reliabel.

Berdasarkan hasil perhitungan uji reliabilitas yang telah dilakukan, didapatkan nilai Cronbach Alfa sebesar 0,609 yang artinya nilai $r$ hitung lebih besar dari nilai $r$ tabel sehingga bisa disimpulkan alat ukur tersebut bersifat reliabel atau dapat dipercaya. Selanjutnya, apabila kita lihat dalam tabel klasifikasi reliabilitas nilai Cronbach Alfa 0,609 terletak diantara 0,6000,800 yang berarti memiliki kriteria reliabilitas tinggi (baik).

4. Mengidentifikasi Persyaratan Teknis (Technical Requirements/Technical Description/Hows)

Pembuatan atribut persyaratan teknis dengan cara menterjemahkan harapan atau keinginan konsumen (whats) ke dalam bentuk karakteristik pengembangan produk yang perlu dilakukan sehingga dapat memenuhi harapan dan keinginan konsumen terhadap produk kerupuk jambu biji merah (lihat tabel 4). Persyaratan teknis ini akan menempati bagian atap rumah dari House of Quality.

Hasil dan pembahasan menyajikan penjabaran data hasil penelitian yang dilengkapi dengan tabel dan gambar. Data hasil yang didapatkan dilakukan proses analisis dan dijelaskan secara terperinci sebab akibat dari data hasil yang didapatkan dan mengaitkan dengan sumber rujukan yang relevan.

5. Mengidentifikasi Hubungan Antar Keinginan Konsumen Dengan Persyaratan Teknis (Whats And Hows) Atau Disebut Dengan Relationship Matriks

Pembuatan matriks hubungan bertujuan untuk mengetahui hubungan antara persyaratan teknis dan atribut keinginan konsumen terhadap produk jambu biji merah. Pada penyusunan matriks ini, digunakan simbol untuk menyatakan derajat hubungan antara atribut keinginan konsumen dengan persyaratan teknis. Pembuatan matrik korelasi ini dilakukan oleh peneliti dari hasil diskusi dengan dosen pembimbing yang merupakan akademisi bidang pangan dan salah satu mahasiswa sebagai pelaku usaha atau pembuat kerupuk jambu biji merah.

Tabel 4 Atribut persyaratan teknis

\begin{tabular}{ll}
\hline Variabel & Atribut Persyaratan Teknis \\
\hline Produk & Sortasi bahan baku \\
& Bahan baku utama dari buah \\
& jambu biji merah yang sudah \\
& matang \\
& Konsentrasi jambu biji merah \\
& dalam adonan \\
& Konsentrasi tapioka dalam \\
& adonan \\
& Konsentrasi soda kue dalam \\
& adonan \\
& Konsentrasi penambahan air \\
& dalam adonan \\
& Lama waktu pengukusan \\
& Lama waktu pengeringan \\
& Lama waktu penggorengan \\
& Bahan kemasan \\
& Ukuran kemasan \\
Kemasan & Informasi pada label kemasan \\
& lengkap \\
& Desain label kemasan menarik \\
& Harga terjangkau sesuai berat \\
& produk per kemasan \\
& Produk mudah didapat
\end{tabular}

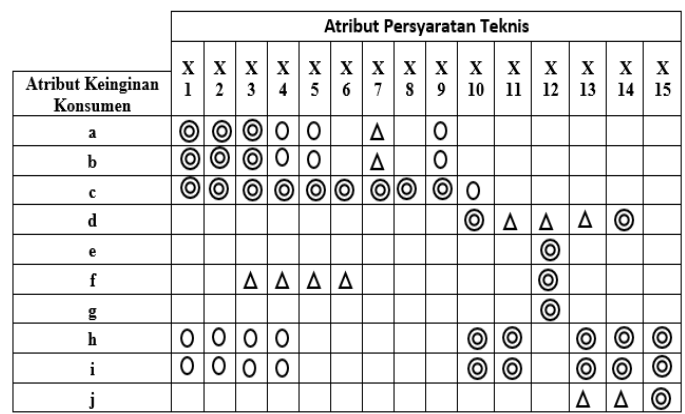

Gambar 2 Matriks hubungan (relationship matrix)

6. Mengidentifikasi Hubungan Antar Persyaratan Teknis (Hows And Hows) Atau Disebut Dengan Interrelationship Matriks

Pembuatan matriks korelasi bertujuan untuk mengetahui hubungan antar persyaratan teknis dari produk kerupuk jambu biji merah. Pada penyusunan matriks ini, digunakan simbol untuk menyatakan derajat hubungan antar persyaratan teknis. 
Pembuatan matrik ini dilakukan oleh peneliti dari hasil diskusi dengan dosen pembimbing yang merupakan akademisi bidang pangan dan salah satu mahasiswa sebagai pelaku usaha atau pembuat kerupuk jambu biji merah.

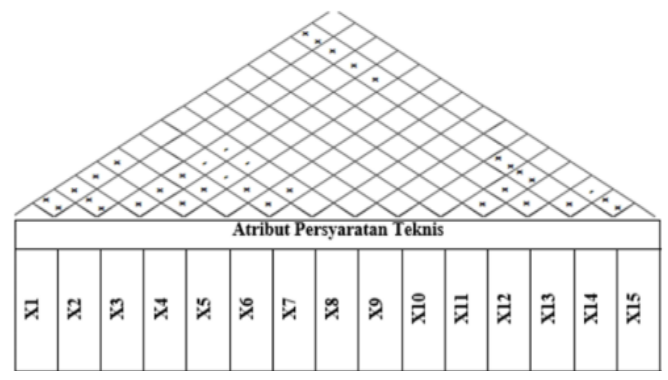

Gambar 3 Matriks korelasi (interrelationship matrix)

7. Menyusun Matriks Perencanaan

a) Menentukan tingkat kepentingan keinginan konsumen (Importance to Customer)

Analisa tingkat kepentingan konsumen dilakukan untuk mengetahui atribut kebutuhan konsumen yang dirasa paling penting oleh konsumen. Hasil analisa tingkat keinginan konsumen dijadikan referensi atau acuan untuk mengetahui preferensi konsumen terhadap kerupuk jambu biji merah. Atribut keinginan konsumen yang memiliki bobot kepentingan tertinggi, menunjukkan bahwa atribut tersebut sangat berpengaruh pada preferensi konsumen ketika membeli kerupuk jambu biji merah. Untuk menentukan tingkat kepentingan masing-masing atribut keinginan konsumen, peneliti melakukan survei dalam bentuk kuesioner kepada 100 responden. Responden yang diambil adalah responden yang sesuai dengan kriteria yang telah ditentukan oleh peneliti. Dalam pengisian kuesioner menggunakan skala likert sebagai penilaiannya yaitu:

$1=$ Sangat Tidak Penting $=$ STP

$2=$ Tidak Penting $=$ TP

$3=$ Netral $=\mathrm{N}$

$4=$ Penting $=\mathrm{P}$

$5=$ Sangat Penting $=S P$
Tabel 5 Bobot kepentingan keinginan konsumen

\begin{tabular}{llll}
\hline NO & Atribut Keinginan Konsumen & $\begin{array}{l}\text { Bobot } \\
\text { Kepentingan }\end{array}$ & Rating \\
\hline 1 & Rasa original & $\mathbf{4 , 1 7}$ & 9 \\
2 & Aroma khas jambu biji merah & $\mathbf{4 , 5 5}$ & 3 \\
3 & Tekstur renyah dan halus & $\mathbf{4 , 4 9}$ & 5 \\
4 & Dikemas menggunakan kemasan plastik & $\mathbf{4 , 1 8}$ & 8 \\
& ziplock & & \\
5 & Informasi tanggal produksi dan tanggal & $\mathbf{4 , 6 9}$ & 1 \\
& kadaluarsa & & \\
6 & Informasi komposisi produk & $\mathbf{4 , 4 9}$ & 4 \\
7 & Informasi produsen dan label merk & $\mathbf{4 , 5 6}$ & 2 \\
8 & Harga Rp 7500 per 100 gram produk & $\mathbf{4 , 2 1}$ & 7 \\
9 & Harga Rp 12500 per 150 gram produk & 3,54 & 10 \\
10 & Dijual di warung/toko dan online shop & $\mathbf{4 , 2 8}$ & 6 \\
\hline
\end{tabular}

Berdasarkan perhitungan tingkat kepentingan konsumen terhadap produk kerupuk jambu biji merah, atribut informasi tanggal produksi dan tanggal kadaluarsa pada kemasan merupakan atribut yang memiliki bobot kepentingan tertinggi $(4,69)$. Hal ini menunjukkan bahwa atribut informasi tanggal produksi dan tanggal kadaluarsa pada label kemasan merupakan atribut yang paling berpengaruh terhadap preferensi konsumen ketika ingin membeli kerupuk jambu biji merah.

Hal pertama yang akan dilakukan konsumen sebelum membeli kerupuk jambu biji merah adalah melihat informasi tanggal produksi dan tanggal kadaluarsa produk pada label kemasan. Menurut peneliti, konsumen ingin memastikan bahwa produk yang dibeli aman untuk dikonsumsi. Sedangkan atribut keinginan konsumen yang memiliki bobot kepentingan terkecil $(3,54)$ adalah harga RP 12.500 per 150 gram berat produk. Hal ini menunjukkan bahwa atribut harga Rp 12500 menjadi atribut yang paling tidak dipertimbangkan atau tidak disarankan konsumen ketika ingin membeli kerupuk jambu biji merah.

b) Analisis tingkat kepuasan konsumen (Customer Satisfaction Performance)

Analisa tingkat kepuasan konsumen dilakukan untuk mengetahui bagaimana tingkat kepuasan konsumen terhadap produk kerupuk jambu biji merah. Data mengenai tingkat kepuasan konsumen didapatkan dari hasil kuesioner secara langsung kepada 100 responden. 
Berdasarkan perhitungan bobot kepuasan konsumen terhadap kerupuk jambu biji merah, atribut informasi tanggal produksi dan tanggal kadaluarsa pada label kemasan merupakan atribut yang memiliki bobot kepuasan tertinggi $(4,86)$. Hal ini menunjukkan bahwa konsumen merasa sangat puas karena dalam kemasan kerupuk jambu biji merah terdapat informasi tanggal produksi dan tanggal kadularsa produk, sehingga konsumen bisa mengetahui kapan produk tersebut diproduksi dan kapan produk tersebut kadaluarsa. Selain itu konsumen juga bisa memastikan bahwa kerupuk jambu biji merah tersebut masih aman untuk dikonsumsi. Sedangkan untuk atribut harga Rp 12500 per 150 gram berat produk merupakan atribut dengan bobot kepuasan terendah $(3,90)$. Menurut peneliti konsumen merasa kurang puas jika harga kerupuk jambu biji merah Rp 12500 per 150 gram berat produk, dikarenakan ada karakteristik atau atribut produk yang tidak sesuai keinginan konsumen sehingga harga tersebut dianggap terlalu mahal.

\section{Tabel 6 Hasil Bobot Kepuasan Konsumen}

\begin{tabular}{|c|c|c|c|}
\hline NO & Atribut Keinginan Konsumen & $\begin{array}{l}\text { Bobot } \\
\text { Kepuasan }\end{array}$ & Rating \\
\hline 1 & Rasa original & 4,39 & 8 \\
\hline 2 & Aroma khas jambu biji merah & 4,63 & 5 \\
\hline 3 & Tekstur renyah dan halus & 4,02 & 9 \\
\hline 4 & $\begin{array}{l}\text { Dikemas menggunakan kemasan plastik } \\
\text { ziplock }\end{array}$ & 4,79 & 3 \\
\hline 5 & $\begin{array}{l}\text { Informasi tanggal produksi dan tanggal } \\
\text { kadaluarsa }\end{array}$ & 4,86 & 1 \\
\hline 6 & Informasi komposisi produk & 4,82 & 2 \\
\hline 7 & Informasi produsen dan label merk & 4,78 & 4 \\
\hline 8 & Harga Rp 7500 per 100 gram produk & 4,60 & 6 \\
\hline 9 & Harga Rp 12500 per 150 gram produk & 3,90 & 10 \\
\hline 10 & Dijual di warung/toko dan online shop & 4,42 & 7 \\
\hline
\end{tabular}

c) Menentukan nilai target (goal)

Nilai Goal ditetapkan untuk menunjukkan sasaran yang ingin dicapai perusahaan, yaitu dengan menilai seberapa jauh perusahaan ingin memenuhi kebutuhan konsumen dengan pertimbangan apakah kebutuhan konsumen tersebut dapat terpenuhi atau tidak. Nilai target didapatkan dengan menggunakan nilai tertinggi dari perbandingan antara tingkat kepentingan konsumen (TKK) dan tingkat kepuasan konsumen (TKP) untuk masing-masing atribut kebutuhan konsumen.

Tabel 7 Nilai target

\begin{tabular}{llll}
\hline Atribut Keinginan Konsumen & TKK & TKP & Goal \\
\hline Rasa original & 4,17 & 4,39 & 4,39 \\
Aroma khas jambu biji merah & 4,55 & 4,63 & 4,63 \\
Tekstur renyah dan halus & 4,49 & 4,02 & 4,49 \\
Dikemas menggunakan kemasan plastik ziplock & 4,18 & 4,79 & 4,79 \\
Informasi tanggal produksi dan tanggal kadaluarsa & 4,69 & 4,86 & 4,86 \\
Informasi komposisi produk & 4,49 & 4,82 & 4,82 \\
Informasi produsen dan label merk & 4,56 & 4,78 & 4,78 \\
Harga Rp 7500 per 100 gram produk & 4,21 & 4,60 & 4,60 \\
Harga Rp 12500 per 150 gram produk & 3,54 & 3,90 & 3,90 \\
Dijual di warung/toko dan online shop & 4,28 & 4,42 & 4,42 \\
\hline
\end{tabular}

Berdasarkan perhitungan nilai target (goal) atribut informasi tanggal produksi dan tanggal kadaluarsa pada label kemasan, informasi komposisi produk dan dikemas menggunakan kemasan ziplock merupakan tiga atribut yang memiliki nilai target tertinggi. Hal ini menunjukkan bahwa tiga atribut tersebut diharapkan menjadi sasaran utama perusahaan untuk memenuhi keinginan konsumen terhadap kerupuk jambu biji merah.

d) Menentukan nilai rasio perbaikan (Improvement Ratio)

Improvement ratio (rasio perbaikan) adalah perbandingan antara sasaran yang ingin dicapai dengan tingkat kepuasan pelanggan dengan produk yang dibuat. Perhitungan improvement ratio dilakukan untuk mengetahui apakah perlu dilakukan perbaikan atau tidak terhadap suatu atribut kebutuhan konsumen. Jika nilai improvement ratio lebih dari 1 maka atribut tersebut harus diperbaiki guna meningkatkan kepuasan konsumen. Apabila nilai improvement ratio sama dengan 1 , maka produk tersebut telah mampu memuaskan keinginan konsumen. Perhitungan rasio perbaikan (Improvement Ratio) dilakukan dengan membagi nilai target (goal) dengan tingkat kepuasan konsumen (Customer Satisfaction Performance) (lihat tabel 8).

Berdasarkan hasil perhitungan improvement ratio, terdapat satu atribut yang memiliki nilai lebih dari 1 yaitu atribut tekstur renyah dan halus $(1,12)$. Hal ini menunjukkan bahwa atribut tekstur renyah dan halus belum sesuai dengan ekspektasi harapan konsumen sehingga perlu dilakukan tindakan perbaikan. 
e) Menentukan poin penjualan (Sales Point) Poin penjualan (Sales Point) dilakukan untuk mengetahui bagaimana peranan masing-masing atribut kebutuhan konsumen terhadap penjualan produk. Penetapan nilai Sales Point didasarkan pada nilai kepentingan konsumen. Untuk kebutuhan konsumen dengan nilai TKK > 3, maka ditetapkan nilai Sales Point sebesar 1,5 (Strong Sales Point). Apabila kebutuhan tersebut terpenuhi maka akan terjadi peningkatan penjualan. Untuk kebutuhan konsumen dengan nilai 2 < TKK $\leq 3$, maka ditetapkan nilai Sales Point sebesar 1,2 (Medium Sales Point). Apabila kebutuhan tersebut terpenuhi maka akan terjadi peningkatan penjualan, walau tidak terlalu besar. Untuk kebutuhan konsumen dengan nilai TKK $\leq 2$, maka ditetapkan nilai Sales Point sebesar 1 (No Sales Point). Apabila kebutuhan tersebut terpenuhi maka tidak akan terjadi peningkatan penjualan.

Tabel 9 Nilai sales point

\begin{tabular}{llc}
\hline Atribut Keinginan Konsumen & TKK & Poin Penjualan \\
\hline Rasa original & 4,17 & 1,5 \\
Aroma khas jambu biji merah & 4,55 & 1,5 \\
Tekstur renyah dan halus & 4,49 & 1,5 \\
Dikemas menggunakan kemasan plastik ziplock & 4,18 & 1,5 \\
Informasi tanggal produksi dan tanggal kadaluarsa & 4,69 & 1,5 \\
Informasi komposisi produk & 4,49 & 1,5 \\
Informasi produsen dan label merk & 4,56 & 1,5 \\
Harga Rp 7500 per 100 gram produk & 4,21 & 1,5 \\
Harga Rp 12500 per 150 gram produk & 3,54 & 1,5 \\
Dijual di warung/toko dan online shop & 4,28 & 1,5
\end{tabular}

Berdasarkan perhitungan sales point pada sepuluh atribut keinginan konsumen, didapatkan hasil bahwa semua atribut memiliki nilai sales point sebesar 1,5 yang berarti bahwa semua atribut keinginan konsumen tersebut sangat berpengaruh terhadap penjualan produk. Jika semua atribut tersebut terpenuhi maka akan terjadi peningkatan penjualan.

f) Menentukan nilai Raw Weight dan Normalized Raw Weight

Raw weight merupakan bobot dari setiap atribut kebutuhan konsumen. Semakin besar nilai Raw Weight suatu atribut, semakin tinggi prioritas pengembangannya. Data ini didapatkan dari hasil perkalian data tingkat kepentingan konsumen, rasio perbaikan dan poin penjualan untuk masing-masing atribut kebutuhan konsumen. Normalized raw weight merupakan persentase bobot suatu atribut kebutuhan konsumen terhadap keseluruhan bobot atribut kebutuhan konsumen untuk setiap atribut kebutuhan atau persen total dari Raw Weight. Hasil perhitungan nilai Raw Weight dan Normalized Raw Weight digunakan untuk menentukan prioritas persyaratan teknis yang harus diutamakan.

Tabel 10 Nilai Raw Weight dan Normalized Raw Weight

\begin{tabular}{llllll}
\hline Atribut Keinginan Konsumen & TKK & IR & SP & RW & NRW \\
\hline Rasa original & 4,17 & 1 & 1,5 & 6,26 & 0,095 \\
Aroma khas jambu biji merah & 4,55 & 1 & 1,5 & 6,83 & 0,104 \\
Tekstur renyah dan halus & 4,49 & 1,12 & 1,5 & 7,54 & 0,115 \\
Informasi tanggal produksi dan tanggal & 4,69 & 1 & 1,5 & 7,04 & 0,107 \\
kadaluarsa & & & & & \\
Informasi komposisi produk & 4,49 & 1 & 1,5 & 6,74 & 0,103 \\
Informasi produsen dan label merk & 4,56 & 1 & 1,5 & 6,84 & 0,104 \\
Harga Rp 7500 per 100 gram produk & 4,21 & 1 & 1,5 & 6,32 & 0,096 \\
Harga Rp 12500 per 150 gram produk & 3,54 & 1 & 1,5 & 5,31 & 0,081 \\
Dijual di warung/toko dan online shop & 4,28 & 1 & 1,5 & 6,42 & 0,098 \\
\multicolumn{1}{c}{ Jumlah } & & & & 65,55 & \\
\hline
\end{tabular}

Keterangan: KK (Importance Rating); IR (Improvement Ratio); SP (Sales Point); RW (Raw Weight); NRW (Normalized Raw Weight).

8. Menentukan Nilai Prioritas dan Kontribusi Persyaratan Teknis

Nilai prioritas persyaratan teknis menunjukkan seberapa penting suatu persyaratan teknis untuk dikembangkan. Semakin tinggi nilai prioritas suatu persyaratan teknis, maka semakin tinggi pula prioritas persyaratan teknis tersebut untuk dikembangkan. Nilai prioritas persyaratan teknis didapatkan dari nilai hubungan pada matriks korelasi dan nilai normalized raw weight. Kontribusi menunjukan kekuatan persyaratan teknis pada keseluruhan persyaratan teknis terhadap kepuasan konsumen. Kontribusi ditentukan dengan menghitung nilai prioritas dibagi dengan total nilai prioritas (lihat Tabel 11).

Berdasarkan perhitungan nilai prioritas dan kontribusi, atribut persyaratan teknis yang menjadi prioritas utama untuk dikembangkan adalah konsentrasi jambu biji merah dalam adonan dengan nilai prioritas $3,460(10,4 \%)$. Atribut persyaratan teknis tersebut menjadi prioritas utama untuk dikembangkan karena mempengaruhi sebagian besar atribut persyaratan konsumen. 
Tabel 11 Nilai Prioritas dan Kontribusi

\begin{tabular}{llll}
\hline Atribut Persyaratan Teknis & $\begin{array}{l}\text { Nilai } \\
\text { Prioritas }\end{array}$ & Kontribusi & Rating \\
\hline Sortasi bahan baku & 3,357 & 0,100 & 2 \\
Bahan baku utama dari buah jambu biji & 3,357 & 0,100 & 3 \\
merah yang sudah matang & & & \\
Konsentrasi jambu biji merah dalam adonan & 3,460 & 0,104 & 1 \\
Konsentrasi tapioka dalam adonan & 2,266 & 0,068 & 8 \\
Konsentrasi soda kue dalam adonan & 1,735 & 0,052 & 10 \\
Konsentrasi penambahan air dalam adonan & 1,138 & 0,034 & 14 \\
Lama waktu pengukusan & 1,234 & 0,037 & 13 \\
Lama waktu pengeringan & 1,035 & 0,031 & 15 \\
Lama waktu penggorengan & 1,632 & 0,049 & 12 \\
Bahan kemasan & 2,802 & 0,084 & 5 \\
Ukuran kemasan & 1,689 & 0,051 & 11 \\
Informasi pada label kemasan lengkap & 2,895 & 0,087 & 4 \\
Desain label kemasan menarik & 1,787 & 0,053 & 9 \\
Harga terjangkau sesuai berat produk per & 2,555 & 0,076 & 6 \\
kemasan & 2,475 & 0,074 & 7 \\
Produk mudah didapat & 33,417 & & \\
Jumlah & & & \\
\hline
\end{tabular}

Atribut persyaratan teknis yang perlu dikembangkan selanjutnya adalah sortasi bahan baku dan bahan baku utama yang digunakan adalah buah jambu biji merah yang sudah matang. Jika atribut persyaratan teknis tersebut dapat dikembangkan maka kepuasan konsumen terhadap kerupuk jambu biji merah akan meningkat.

\section{Matriks House of Quality}

Semua data atau informasi dari tahapan-tahapan sebelumnya dimasukkan ke dalam matriks HOQ berdasarkan bagiannya masing-masing (lihat Gambar 4).

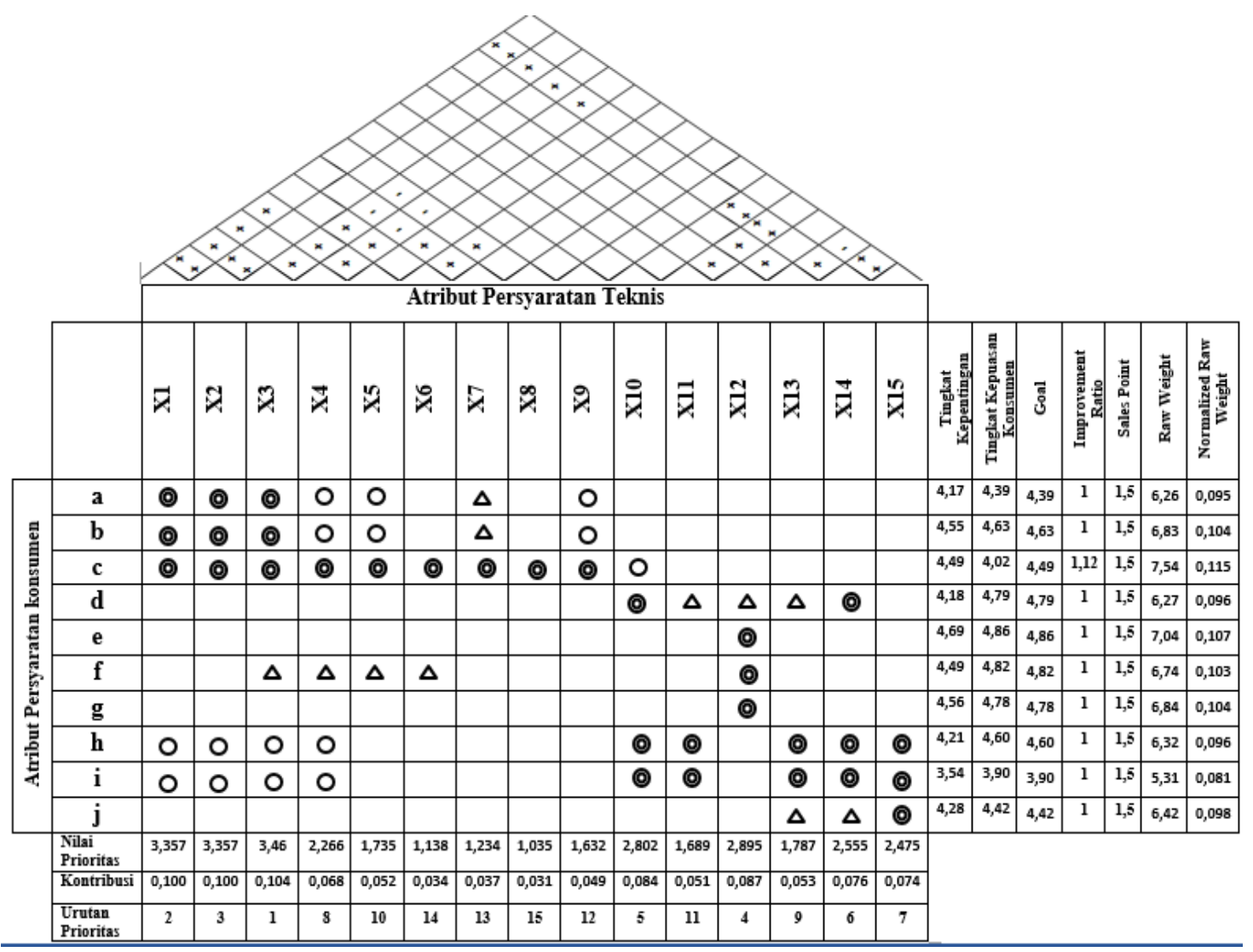

Gambar 4 Matriks house of quality kerupuk jambu biji merah

Keterangan gambar :

1. Simbol Interrelationship Matrix

$++=$ menunjukkan hubungan positif kuat

$+=$ menunjukkan hubungan positif

- = menunjukkan hubungan negatif

-- = menunjukkan hubungan negatif kuat

Tanpa simbol $=$ menunjukkan tidak ada hubungan.
2. Simbol Relashionship Matrix:

(0) = menunjukkan hubungan yang kuat, bernilai 9

$\mathrm{O}$ = menunjukkan hubungan sedang, bernilai 3

$\triangle=$ menunjukkan hubungan lemah, bernilai 1

Tanpa simbol = menunjukkan tanpa hubungan, tidak ada nilai. 
3. Atribut keinginan konsumen

a. = Rasa original

b. = Aroma khas jambu biji merah

c. = Tekstur renyah dan halus

d. = Dikemas menggunakan kemasan plastik ziplock

e. = Informasi tanggal produksi dan tanggal kadaluarsa

f. $=$ Informasi komposisi produk

g. = Informasi produsen dan label merk

h. $=$ Rp 7500 per 100 gram produk

i. $=$ Rp 12500 per 150 gram produk

j. = Dijual di warung dan online shop

4. Atribut persyaratan teknis

X1 = Sortasi bahan baku

X2 = Bahan baku utama dari buah jambu biji merah yang sudah matang

X3 = Konsentrasi jambu biji merah dalam adonan

X4 = Konsentrasi tapioka dalam adonan

X5 = Konsentrasi soda kue dalam adonan

X6 $=$ Konsentrasi penambahan air dalam adonan

X7 = Lama waktu pengukusan

$X 8$ = Lama waktu pengeringan

X9 = Lama waktu penggorengan

X10 = Bahan kemasan

$\mathrm{X} 11=$ Ukuran kemasan

X12 = Informasi pada label kemasan lengkap

X13 = Desain label kemasan menarik

X14 = Harga terjangkau sesuai berat produk per kemasan

$\mathrm{X} 15=$ Produk mudah didapat

\section{SIMPULAN}

Berdasarkan hasil penyebaran kuesioner terdapat sepuluh atribut keinginan konsumen terhadap produk kerupuk jambu biji merah antara lain rasa original, aroma khas jambu biji merah, tekstur renyah dan halus, dikemas menggunakan kemasan plastik ziplock, informasi tanggal produksi dan tanggal kadaluarsa, informasi komposisi produk, informasi produsen dan label merk, harga Rp 7500 per 100 gram produk, harga Rp 12500 per 150 gram produk dan dijual di warung/toko dan online shop.

Semua atribut sudah bisa memuaskan konsumen (IR=1) kecuali atribut tekstur renyah dan halus yang belum sesuai dengan ekspektasi konsumen terhadap kerupuk jambu biji merah $(1,12>1)$ sehingga diperlukan adanya tindakan perbaikan.

Konsentrasi jambu biji merah dalam adonan merupakan atribut persyaratan teknis dengan nilai prioritas tertinggi yaitu $3,460(10,4 \%)$, sehingga atribut tersebut menjadi prioritas utama untuk dikembangkan agar bisa meningkatkan kepuasan konsumen terhadap produk kerupuk jambu biji merah. Informasi tanggal produksi dan tanggal kadaluarsa pada label kemasan merupakan atribut keinginan konsumen yang memiliki bobot kepentingan tertinggi yaitu 4,69. Hal ini menunjukkan bahwa atribut informasi tanggal produksi dan tanggal kadaluarsa pada label kemasan merupakan atribut yang paling berpengaruh ketika konsumen ingin membeli kerupuk jambu biji merah.

\section{DAFTAR PUSTAKA}

Akao, Y., 1990. Quality Function Deployment (QFD) - Integrating customers's requirements into product design, English translation copyright.,USA: Productivity Press.

Andayani, A., et al., 2015. Desain Produk Makanan Ringan untuk Ibu Hamil dengan Menggunakan Quality Function Deployment (QFD). Jurnal Agroindustri, Vol.4, No. 1.

Cohen, L., 1995. Quality Function Deployment, How to make QFD Work for You., New York: Addison-Wesley Publishing Company.

Day, B.G., 1993. Quality Function Deployment: Lingking A Company with Its Customer.,Milwaukee: ASQC Quality Press

Gaspersz, V., 2001. Metode Analisis untuk Peningkatan Kualitas., Jakarta: PT. Gramedia Pustaka Utama.

Kotler, P., 2002. Manajemen Pemasaran, Edisi Milenium Jilid 1., Jakarta: Prebalindo.

Milton D.R. et al., 1993. Managing The Development Of New Product.,New York: Van Nostrand Reinhold.

Nasution, M. N., 2005. Manajemen Mutu Terpadu (Total Quality Management)., Bogor: Ghalia Indonesia.

Retnowati, N., 2013. Penerapan Metode Quality Function Deployment (QFD) pada Produk Tempe (Studi Kasus pada Perusahaan "Sumber Rejeki"). Jurnal Ilmiah Inovasi, Vol.13, No.2.

Veronica, H dan Yurida, E., 2014. Perencanaan Produk Olahan Wortel Menggunakan Metode Quality Function Deployment (QFD). Jurnal Ilmiah, Vol.1, No.1. 
